\title{
Analysis of Human Resource Competency as Effort to Increase SMEs Economic Sector Productivity with Gender as Differentiating Variable
}

\author{
Dian Prihardini Wibawa \\ Faculty of Economics, Bangka Belitung University, Indonesia \\ dianpw.mustafa@gmail.com
}

\begin{abstract}
Competence is a very important factor in increasing work productivity. A qualified workforce will have a positive impact on improving business productivity. Thus, the level of corporate profitability also increased. Human resource improvement strategy is an excellent strategy apart from other factors such as technology improves. Increased strategy through human resource competence can be done with the improvement of ability, attitude, knowledge, and expertise. The purpose of this research is to see the influence of human resource competence on the productivity of small and medium business actors with gender variable as differentiator variable in Pangkalpinang city. The result of this research indicates the male labour variable of competency which influence productivity is only knowledge variable, while other variables have no effect. While for women the ability variable, skill and knowledge have an effect on to productivity.
\end{abstract}

Keywords: Competence of human resources, Gender, Productivity

\section{Introduction}

A good economic level is a very important indicator in the development of a country. Economic growth can be seen from the increasing amount of industrial goods production, the development of infrastructure, the increase of educational facilities and infrastructure, as well as the increase of capital goods production and the increase of service sector. The measure commonly used to measure the economic growth of a country is with the value of Gross Domestic Product (GDP) with the concept of national income. GDP is one method of measuring national income. GDP is defined as the market value of all goods and services produced by a country within a certain period of time (per year). Meanwhile, to measure the level of economic growth of a region using the size of Gross Regional Domestic Product (GRDP) based on constant prices and prices apply. The economy in Indonesia in 2016 as published by the Central Bureau of Statistics measured based on GDP at current prices reaches Rp 12.406.8 trillion and GDP per capita reaches Rp 47.96 million or $\$ 3,605.1$. This shows the Indonesian economy grew 5.02 percent in 2016 compared with the previous year with a growth rate of 4.88 percent. The contribution of the micro, small and medium enterprises (MSME) to GDP sector has increased considerably in the 
past five years, namely 57.84 percent to 60.34 percent. This shows that the role of UMKM is very big in the nation's economy.

In Bangka Belitung Province, economic growth in 2016 in the first quarter, according to the Regional Economic and Financial Study Book (KEKR) published by the Representative Office of Bank Indonesia Province of Bangka Belitung Islands experienced a slowdown. In Q1 / 2016, Bangka Belitung's economy measured based on GDP at constant prices reached Rp11,568 billion or grew by $3.30 \%$ (yoy), down from $4.28 \%$ (yoy) in the preceding quarter. In Q2 / 2016, Bangka Belitung's economy measured based on GDP at constant prices reached Rp11,875 billion, or grew by 3.67\% (yoy), up from the previous quarter. In Q3 / 2016, Bangka Belitung's economy measured based on GDP at constant prices reached Rp12,002 billion or grew by $3.83 \%$ (yoy), up from 3.68\% (yoy) in the previous quarter. The increasing economic growth of Bangka Belitung is driven by components of Non-Profit Household Institution (LNPRT), household consumption and investment. $3.32 \%$ (yoy).

The slowing down of Pangkalpinang's economic growth is also influenced by the productivity of small and medium enterprises (UMKM). Whereas the role of MSMEs in the economy is very important. Viewed from the level of labour productivity in Pangkalpinang city, there was a decrease in the last year. This can be seen from the following table:

Table 1. Level of Labor Productivity Pangkalpinang

\begin{tabular}{lc}
\hline Year & Amount of Labor Force \\
\hline 2010 & 82.991 \\
2011 & 85.851 \\
2012 & 89.611 \\
2013 & 90.218 \\
2014 & 92.779 \\
2015 & 88.302 \\
\hline
\end{tabular}

Source: BPS Pangkalpinang, processed, 2017

The number of perpetrators of UMKM in Pangkalpinang every year continues to increase. Based on data taken from the industry, trade, cooperatives and SMEs Pangkalpinang city, until the end of 2016, the number of perpetrators of SMEs in the city of Pangkalpinang there are 12,767. This study aims to analyze the influence of human resource competence (Ability, Attitude, Knowledge, and Skill) in an effort to increase the productivity of SMEs by comparing male and female respondents.

\section{Literature Review}

It is very important for companies to increase the productivity of work high or tends to increase, because with the increasing productivity of human resources work, then the effectiveness and efficiency of the company will increase as well. Increasing productivity is not an easy thing to do, but it is not impossible to do. Some of the factors that affect the level of productivity include: Education and training, Nutrition and health, Motivation, Job Opportunity, Achievement, Government policy, Employee skills, Technology, Environment and work climate, Attitudes and work ethic, Discipline, Compensation and Competency. 


\section{IJBE: Integrated Journal of Business and Economics}

e-ISSN: 2549-3280

Competence is defined (Mitrani et al., 1992; Spencer and Spencer, 1993) in IDKR Ardiana et al. (2010) as an underlying characteristic of an individual which is causally related to criterionreferenced effective and or superior performance in a job or situation. Or the underlying characteristics of a person and related to the effectiveness of individual performance in his work. Departing from that understanding the competence of an individual is something inherent in him that can be used to predict 6 levels of performance. Something that can be concerned with motives, self-concept, nature, knowledge, and ability. Supriyanto and Tri (2013) say that individual competencies in the form of skills and knowledge can be developed through education and training. While the motive of competence can be obtained during the selection process.

Making SMEs more professional, the human factor becomes the main capital; this is because the success of a business unit is determined by how the individuals involved in it manage the business. The performance of a UMKM is always related to the development of its business. However, the development of MSME must be accompanied by the development of Human Resources (Human Resources) in various aspects. But the quality of human resources in need especially in the field of human resource competencies such as knowledge, skills, and ability and attitude in entrepreneurship (I.D.K.R Ardiana et al., 2010). Fatchur Rohman (2016) in his journal said Ability (Ability) is the capacity of an individual to do various tasks in a job. Some ability indicators include the ability to manage a business, make decisions, lead, control, innovate, situations and change the business environment. Someone needs the ability in entrepreneurship so that the business on the road can survive and compete with other businesses.

H1: Ability allegedly partially significant effect on the productivity of economic sector of SMEs in Pangkalpinang city.

Attitude According to Gitosudarmo and Sudita (2008) in the journal Yunita Lidya Kandou (2016) suggests that the attitude/ behaviour of the work is the attitude of the regularity of one's feelings and thoughts and the tendency to act on aspects of the environment. Judge (2010) also explained that attitudes are complex mental states involving beliefs and feelings, and dispositions to act in a certain way. This opinion is further enriched by Ramdhani (cited by Judge, 2010) that attitude is a mental and neural condition derived from experience, which directs and dynamically influences individual responses to all related objects and situations.

$\mathrm{H} 2$ : Attitude allegedly partially significant effect on the productivity of economic sector of UMKM in Pangkalpinang city.

Knowledge (knowledge) is the mastery of science and technology owned by the entrepreneur and obtained through the process of learning and experience of someone in his life. Some knowledge indicators (knowledge) are knowledge of business management, product or service knowledge, consumer knowledge, promotion, and marketing strategy.

H3: Knowledge allegedly partially significant effect on the productivity of economic sector of UMKM in Pangkalpinang city

Skill (Skill) according to Rohman (2016) is a special capacity to manipulate a physical object. Some of the skills indicators include production skills, communication, cooperation and organization, supervision, finance, administration, and accounting. 
H4: Skill allegedly partially significant effect on the productivity of economic sector of UMKM in Pangkalpinang city.

The gender that became the differentiator variable in this research indicates that the difference between male and female employees have an effect on to increase work productivity of UMKM. In this case, the hypothesis is made as follows:

H5: Gender has an effect on increasing productivity of economic sector of UMKM in Pangkalpinang city

\section{Research Methods}

This research is a type of research using quantitative descriptive approach. This research was conducted in Pangkalpinang city with the respondents of the research is the perpetrators of SMEs economic sector. The population in this study is all the perpetrators of SMEs economic sector which amounted to 12,767 respondents.

Table 2. Population of UMKM of Pangkalpinang City in 2016

\begin{tabular}{cccc}
\hline No. & District & Number of MSMEs & Percentage \\
\hline 1. & Bukit Intan & 1.487 & 11,65 \\
2. & Gabek & 1.554 & 12,17 \\
3. & Gerunggang & 2.168 & 16,98 \\
4. & Girimaya & 1.913 & 14,98 \\
5. & Pangkal Balam & 1.315 & 10,30 \\
6. & Rangkui & 2.708 & 21,21 \\
7. & Taman Sari & 1.622 & 12,71 \\
& Total & 12.767 & 100 \\
\hline
\end{tabular}

Source: BPS Pangkalpinang, processed, 2017

This research uses Probability Sampling Technique which is sampling technique which gives equal opportunity for every element (member) of the population to be selected become the member of the sample. To determine the sample size used Slovin formula.

$$
\begin{gathered}
n=\frac{N}{1+N\left(e^{2}\right)} \\
n=\frac{12767}{1+12767\left(0,1^{2}\right)} \\
n=99,22=100
\end{gathered}
$$

Sampling research using technique Proportionate Stratified Random sampling that if the population has members/elements that are not homogeneous and stratified proportionately. The following sampling technique in this research using Proportionate Stratified Random Sampling method. 
IJBE: Integrated Journal of Business and Economics

e-ISSN: 2549-3280

Table 3. Number of Research Sample

\begin{tabular}{clcc}
\hline No & \multicolumn{1}{c}{ District } & Sample Size & Sample \\
\hline 1. & Bukit Intan & $11,65 \% \times 100=11,65$ & 12 \\
2. & Gabek & $12,17 \% \times 100=12,17$ & 12 \\
3. & Gerunggang & $16,98 \% \times 100=16,98$ & 17 \\
4. & Girimaya & $14,98 \% \times 100=14,98$ & 15 \\
5. & Pangkal Balam & $10,30 \% \times 100=10,30$ & 11 \\
6. & Rangkui & $21,21 \% \times 100=21,21$ & 21 \\
7. & Taman Sari & $12,71 \% \times 100=12,71$ & 13 \\
& Total & & 101 \\
\hline
\end{tabular}

Source: BPS Pangkalpinang, processed, 2017

Analysis of research data differentiates between male and female employees to get more effective results and strengthen the research hypothesis. Data analysis techniques in this study using multiple linear regression analysis.

\section{Results}

This research wanted to analyze the influence of competence of human resources (ability, attitude, knowledge, and skill) of UMKM to increase the productivity of economic sector of UMKM in Pangkalpinang by using gender variable as differentiator variable. From the data that have been obtained during the pre-research, there are several types of business: Bangka typical food business (such as Getas, Kericu, Dodol Ketan, Chips and Crackers), Bricks, Furniture and Food Street (Mie Kuah Ikan, Pantiaw, Pempek and others), Sewing Services, Grocery Stores and More, Handicraft Business.

The distribution of questionnaires was conducted by 101 researchers of MSMEs in Pangkalpinang involving several enumerators. The timeframe for distributing questionnaires is 3 days which is done by direct supervision and monitoring of business by the enumerator. The number of the distributed questionnaire can be explained in table 4 below:

Table 4. Distribution of Questionnaires

\begin{tabular}{lc}
\hline \multicolumn{1}{c}{ Information } & Total \\
\hline Distributed questionnaire & 101 unit \\
The questionnaire has not returned yet & 0 unit \\
The returned questionnaire & 10 unit \\
Questionnaires used in the study & 101 unit \\
\hline
\end{tabular}

Source: Data processed, 2017

From the results of data validity test analysis, it can be said that all the instrument questions tested its validity. It can be seen from the value of r-value of each instrument of the question asked bigger than $r$ table value (0.1646) so that all question instrument can be used in this research. Instruments that have been tested the level of validity then will be tested the level of reliability. Reliability with regard to the level of reliability or determination of measurement results (Sukmadinata, 2009). Ghozali (2009) states that reliability is a tool to measure a questionnaire that is an indicator or a variable or constructs. The high level of reliability is 
indicated by the value of the reliability coefficient. Of the four variables used, the skill variable has an alpha value of 0.642 , which is categorized to moderate (moderate) reliability.

From testing the classical assumptions as a whole (normality test, heteroscedasticity test, multicollinearity test, and autocorrelation) fulfilled all requirements. Based on the test of normality (for 101 respondents) with Kolmogorov-Smirnov Test obtained KSZ value of 0.104 and Asymp. Sig of 0.118 greater than 0.05 which can be inferred carry normally distributed data.

Table 5. Test of Kolmogorov Smirnov Normality with 101 Respondents

One-Sample Kolmogorov-Smirnov Test

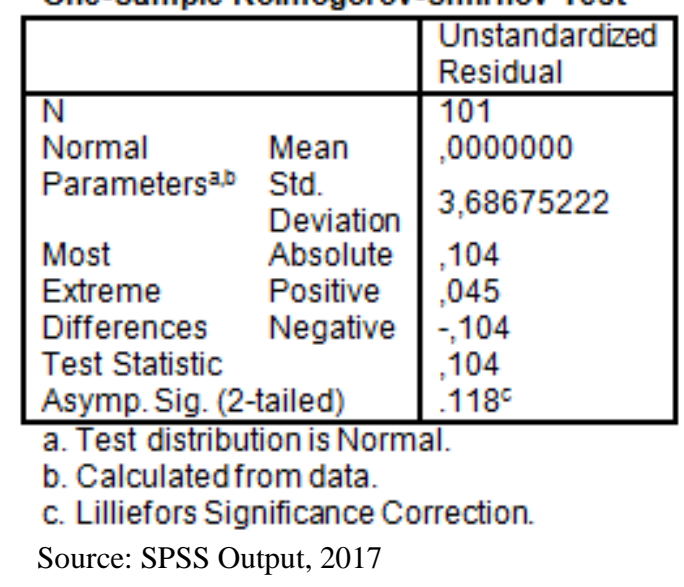

In testing hypothesis by using multiple regression analysis which is the influence of ability (TOTALX1), attitude (TOTALX2), knowledge (TOTALX3), and skill (TOTALX4) to increase the productivity of economic sector of UMKM in Pangkalpinang by using gender as differentiate variable got the result as follows:

Table 6. Hypothesis Testing

\begin{tabular}{|c|c|c|c|c|c|c|c|}
\hline \multirow[b]{2}{*}{ Model } & \multicolumn{2}{|c|}{$\begin{array}{l}\text { Unstandardized } \\
\text { Coefficients }\end{array}$} & \multirow{2}{*}{$\begin{array}{l}\text { Standardized } \\
\text { Coefficients } \\
\text { Beta }\end{array}$} & \multirow[b]{2}{*}{$\mathrm{t}$} & \multirow[b]{2}{*}{ Sig. } & \multicolumn{2}{|c|}{$\begin{array}{l}\text { Collinearity } \\
\text { Statistics }\end{array}$} \\
\hline & B & $\begin{array}{l}\text { Std. } \\
\text { Error }\end{array}$ & & & & Tolerance & VIF \\
\hline 1 (Constant) & 13,692 & 6,248 & & 2,191 & , 031 & & \\
\hline TOTALX1 & ,252 & 117 & 146 & 2,160 & ,033 & ,978 & 1,023 \\
\hline TOTALX2 & ,358 & 164 & 189 & 2,178 & , 032 & ,587 & 1,702 \\
\hline TOTALX3 & ,931 & 179, & 455 & 5,213 & 000 & ,584 & 1,714 \\
\hline TOTALX4 & ,743 & 157 & ,334 & 4,741 &, 000 & 897 & 1,114 \\
\hline
\end{tabular}

Dependent Variable: TOTALY

Source: SPSS Output, 2017

From table 6 result of this research, it can be concluded that competence of human resources (ability, attitude, knowledge, and skill) at UMKM in Pangkalpinang City can increase productivity from UMKM perpetrator. From the test results concluded that the productivity of MSMEs economic sector could be explained by the variables of ability, attitude, knowledge, and skills. It appears that the value of $t$ count is greater than $t$ table 1.984. 
IJBE: Integrated Journal of Business and Economics e-ISSN: 2549-3280

Table 7. Hypothesis Testing with Coefficients Male Respondents

\begin{tabular}{|c|c|c|c|c|c|c|c|c|}
\hline \multirow{2}{*}{\multicolumn{2}{|c|}{ Model }} & \multicolumn{2}{|c|}{$\begin{array}{l}\text { Unstandardized } \\
\text { Coefficients }\end{array}$} & \multirow{2}{*}{$\begin{array}{l}\text { Standardized } \\
\text { Coefficients } \\
\text { Beta }\end{array}$} & \multirow[b]{2}{*}{$\mathrm{t}$} & \multirow[b]{2}{*}{ Sig. } & \multicolumn{2}{|c|}{$\begin{array}{l}\text { Collinearity } \\
\text { Statistics }\end{array}$} \\
\hline & & B & $\begin{array}{l}\text { Std. } \\
\text { Error }\end{array}$ & & & & Tolerance & VIF \\
\hline & (Constant) & 4,579 & 10,896 & & 420 & 677 & & \\
\hline & TOTALX1 & 156 & ,234 &, 087 &, 667 & ,509 & ,988 & 1,012 \\
\hline & TOTALX2 & ,435 &, 311 & 205 & 1,399 & 169 &, 776 & 1,288 \\
\hline & TOTALX3 &, 680 & ,305 &, 343 & 2,227 &, 032 & ,705 & 1,419 \\
\hline & TOTALX4 & ,327 & 198, & ,225 & 1,654 & 106 & ,904 & 1,106 \\
\hline
\end{tabular}

a. Dependent Variable: TOTALY

Source: SPSS Output, 2017

From table 7 of this study, it can be concluded that the competence of human resources from the male SMEs (ability, attitude, knowledge, and skill) in Pangkalpinang City cannot increase the productivity of UMKM. From the test result concluded that productivity of economic sector of UMKM could be explained by knowledge variable. Seen that the value of t count is smaller than t table 2.104. Only knowledge variables of male respondents are influential in improving the productivity of MSMEs.

Table 8. Hypothesis Testing with Female Respondents

\begin{tabular}{|c|c|c|c|c|c|c|c|c|}
\hline \multirow{2}{*}{\multicolumn{2}{|c|}{ Model }} & \multicolumn{2}{|c|}{$\begin{array}{l}\text { Unstandardized } \\
\text { Coefficients }\end{array}$} & \multirow{2}{*}{$\begin{array}{l}\text { Standardized } \\
\text { Coefficients } \\
\text { Beta }\end{array}$} & \multirow[b]{2}{*}{$\mathrm{t}$} & \multirow[b]{2}{*}{ Sig. } & \multicolumn{2}{|c|}{$\begin{array}{l}\text { Collinearity } \\
\text { Statistics }\end{array}$} \\
\hline & & B & $\begin{array}{l}\text { Std. } \\
\text { Error }\end{array}$ & & & & Tolerance & VIF \\
\hline & (Constant) & 16,791 & 7,304 & & 2,299 &, 026 & & \\
\hline & TOTALX1 & ,307 & 150 & 170 & 2,052 &, 045 & ,959 & 1,043 \\
\hline & TOTALX2 & ,236 &, 245 & 129 &, 962 &, 340 &, 367 & 2,722 \\
\hline & TOTALX3 & 1,241 &, 302 & ,545 & 4,108 &, 000 &, 372 & 2,691 \\
\hline & TOTALX4 &, 677 & 175 & ,336 & 3,863 &, 000 &, 867 & 1,153 \\
\hline
\end{tabular}

a. Dependent Variable: TOTALY

Source: SPSS Output, 2017

From table 8 of this research, it can be concluded that the competence of human resources of female employees (ability, attitude, knowledge, and skill) at UMKM in Pangkalpinang City can increase productivity from UMKM. From the test result concluded that productivity of economic sector of UMKM could be explained by the variable of ability, knowledge, and skill. It is seen that the value of $t$ count is greater than t table 2.003. However, attitude variable from female respondents did not have an effect to increase productivity from UMKM.

\section{Conclusion}

From the results of this study, it can be concluded that the competence of human resources (ability, attitude, knowledge, and skill) at SMEs in Pangkalpinang City can increase the productivity of SMEs. From the test results concluded that the productivity of MSMEs economic sector could be explained by the variables of ability, attitude, knowledge, and skills. While the remaining 0.427 or $42.7 \%$ can be explained by other variables that are outside of the variables 
IJBE: Integrated Journal of Business and Economics

e-ISSN: 2549-3280

used in the study. However, when looking from the side of the gender can be concluded that the gender effect in improving UMKM productivity. This can be seen from the hypothesis testing that indicates the female SMEs actors have more competence in boosting the productivity of UMKM.

\section{References}

1) Agustina, Aifrid, 2000, Kompetensi Sumber Daya Manusia dalam meningkatkan Performansi Organisasi, Jurnal Telaah Bisnis volume 2 nomor 1 Juli tahun 2000.

2) Amstrong, Michael, 2004, Performance Management, Edisi Bahasa Indonesia, tugu Publisher, Yogyakarta.

3) Arikunto, Aifrid, 2000, Kompetensi Sumber Daya Manusia dalam meningkatkan Performansi Organisasi, Jurnal Telaah Bisnis volume 2 nomor 1 Juli tahun 2000.

4) Bohlander, Snell, Sherman, 2001, Managing Human Resources, twelfth edition, South Western College-Publishing, USA.

5) Cumming \& Worley, 2005, Organization Development and Change, Eighth Edition, South Western, Thomson, USA.

6) Dunn, William., N, 2002 Analisis Kebijakan Publik (terjemahan), PT. Hanindita, Yogyakarta.

7) Fatchur Rohman, Kompetensi Sdm Dan Pengaruhnya Terhadap Kinerja Karyawan Bagian Akuntansi Ksp Di Kabupaten Jepara, 2016

8) Gibson, Ivancevich, and Donelly, 1997, Organizations : Behavior, Structure, Processes, Ninth Edition, Richard D. Irwin. Inc., USA.

9) Greenberg, Jerald, and Baron, Robert A., 1997, Behavior in Organizations : Understanding and Managing The Human Side of Work, Sixth Edition, Prentice-Hall, Inc., USA.

10) I.D.K.R. Ardiana, I.A. Brahmayanti, Subaedi, Kompetensi SDM UKM Dan Pengaruhnya Terhadap Kinerja UKM Di Surabaya, 2010

11) Idris Yanto Niode, Sektor Umkm Di Indonesia: Profil, Masalah, Dan Strategi Pemberdayaan, 2009

12) Iwan Sidharta Dan Dina Lusyana, Analisis Faktor Penentu Kompetensi Berdasarkan Konsep Knowledge, Skill Dan Ability Disentra Kaos Suci Bandung, 2014

13) Jeffrey Preffer, Budi W. Soetjipto, dkk., 2003, Sumber Daya Manusia Berkualitas Mengubah Visi Menjadi Realitas, Edisi Pertama, PT Gramedia Pustaka Utama, Jakarta.

14) Kuncoro, Mudrajad, 2003, Metode Riset untuk Bisnis \& Ekonomi, Penerbit Erlangga, Jakarta.

15) Michael. E. Porter, 1994, Competitive Advantage (Keunggulan Bersaing), terjemahan, PT. Bina Rupa Aksara, Jakarta.

16) Mursi, Abdul Hamid, 1999, Asy Syakhshiyatul Muntajah (Sumber Daya Manusia yang produktif), terjemahan, cetakan keempat, Penerbit Gema Insani Press, Jakarta.

17) Nurhayati, Siti Fatimah, 2000, Kontribusi Sumber Daya Manusia terhadap Kinerja Perusahaan, Journal Telaah Bisnis volume 1 No.l Juli tahun 2000.

18) Robbins, Stephen P., 1996, Organizational Behavior : Concepts, Controversies, Application, Seventh Edition, Prentice-Hall, Inc., USA.

19) Santoso, Singgih, 1999, SPSS : Mengolah Data Statistik Secara Profesional, PT. Elex Media Komputindo, Jakarta.

20) Schermerhorn, R.J. 1996, Management ( $5^{\text {th }}$ ed) New York : John Wiley \& Sons, Inc.

21) Sekaran, Uma, 2003, Research Methods For Business, Fourth Edition, John Wiley \& Sons, Inc, New York, USA.

22) Singarimbun, Masri dan Effendi, Sofian, 1989, Metode Penelitian Survai, Edisi Revisi, LP3ES, Jakarta.

23) Soegiyono, 2013, Statistika Untuk Penelitian, Alfabeta, Bandung.

24) Tjokrowinoto, Moeljarto, 2004, Birokrasi Dalam Polemik, edisi kedua, Penerbit Pustaka Pelajar dan Universitas Muhammadiyah Malang, Jawa Timur. 
IJBE: Integrated Journal of Business and Economics e-ISSN: 2549-3280

25) Ulrich, D., 1997, Human Resource Champions : The Next Agenda for Adding Value and delivering Result. Boston : Harvard Business Scool Press.

26) Umar, Husein, 1998, Riset sumber Daya Manusia, Edisi Kedua Amara Books, Yogyakarta.

27) Usmara, A., 2002, Paradigma Baru Manajemen Sumber Daya Manusia, Edisi Kedua Amara Books, Yogyakarta.

28) Wiwin Priana Primandhana, Faktor-Faktor Yang Mendorong Kompetensi Ukm Sektor Informal Di Daerah Rungkut Surabaya

29) Yunita Lidya Kandou, Dkk, Pengaruh Knowledge Management, Skill, Dan Attitude Terhadap Kinerja Karyawan (Studi Pada PT. Bank Sulutgo Kantor Pusat Dimanado), 2016 